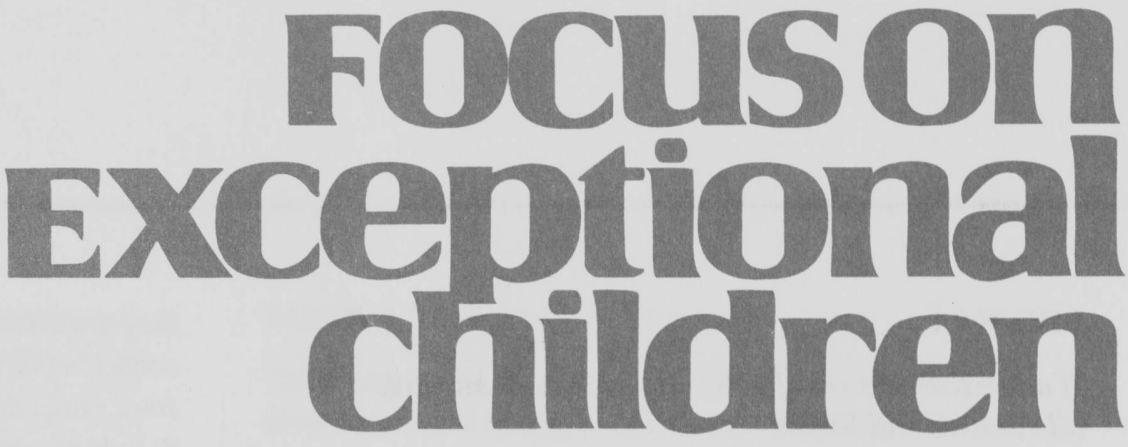

\title{
Eight Myths About Special Education
}

\author{
James M. Kauffman and Patricia L. Pullen
}

Myths about disabilities and about special education are common in the public mind (Hallahan \& Kauffman, 1994). Too often, myths find their way into the perceptions and professional practices of special educators as well. Myths are alluring beliefs; they express something of our fears and hopes. Nevertheless, replacing myths with facts is important, as perceptions and practices based on fictions can have s rin's negative consequences. Understanding the attraction of myths is important, too, for myths sin. 1 remind us of the realities we need to address. A myth typically grows out of the observation of a significant problem and a desire to address it, and the fraction of truth from which the myth grows is a fragment that must not be lost in our attempt to correct a misunderstanding.

The partial truth of a myth makes it hard to combat. A myth is distinguished from reality by its overgeneralization, distortion, or misapplication of fact. The fragment of truth embedded in a myth is much harder to discount than pure fantasy or a full-blown lie. For this reason, in a court of law we may be asked to swear to tell "the truth, the whole truth, and nothing but the truth." We recognize that partial truths are as damaging as complete untruths, if not more so.

For purposes of our discussion, we define a myth as a partial truth that is accepted uncritically, especially in the support of existing or proposed practices. The number of myths influencing special education practice and policy greatly exceeds the number we can discuss in this article. We have chosen only eight that we think are particularly important. For each of these, we first discuss the origins of the partial truth of the myth. Then we describe some of the negative consequences of maintaining the myth and present what we believe to be the whole truth that should replace the myth. We end our discussion of each myth with statements about what the myth should remind us to do, a call to be mindful of the problem or concern that gave rise to the myth, which must be recognized in any attempt to replace the myth with the whole truth.

For the first six myths we provide anecdotes, drawn from our own professional experiences, that run counter to the myths. For the last two myths we provide illustrative quotations from the professional literature. We caution that our anecdotes alone do not provide sufficient evidence to refute the myths. They serve primarily to connect our discussion of the myths to actual teaching experience. Myths themselves often arise from and are perpetuated by anecdotes, and we must be aware that anecdotes alone can be seriously misleading. Ultimately, correcting a myth requires accumulating reliable empirical data and careful logical analysis.

The authors are associated with the University of Virginia Department of Curriculum, Instruction, and Special Education. 


\section{MYTH \# 1}

\section{If a teacher uses an effective instructional method, all students will learn.}

Perhaps it is human nature that teachers always should hope to find a magical method-absolutely reliable, fail-safe, universally applicable to all students who are learning specific skills. No such luck, but the myth lives on. True, some instructional methods are more effective than others, and some produce good results for most of the students with whom they are used. Few developers of curriculum or instructional strategies, however, include explicit plans for dealing with failures. Educators are told to believe not only that all children can learn but actually that all children will learn if only they use method X as prescribed by its developers. The appeal of claiming success for all is overwhelming in a society in which egalitarianism is demanded in education. In today's sociopolitical climate, not claiming that it will provide success for all or candidly admitting that some students will fail is likely to be the kiss of death to an educational endeavor.

One negative consequence of this myth is teacher disillusionment with the introduction of "new" or different approaches, even if they are supported by reliable evidence that

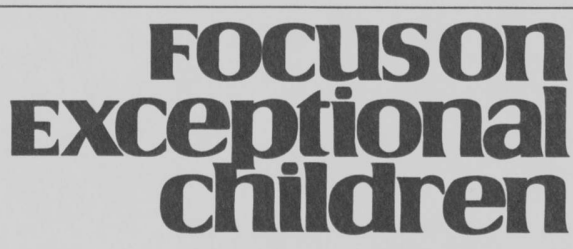

ISSN 0015-511X

FOCUS ON EXCEPTIONAL CHILDREN (USPS 203-360) is published monthly except June, July, and August as a service to teachers, special educators, curriculum specialists, administrators, and those concerned with the special education of exceptional children. This publication is annotated and indexed by the ERIC Clearinghouse on Handicapped and Gifted Children for publication in the monthly Current Index to Journals in Education (CIJE) and the quarterly index, Exceptional Children Education Resources (ECER). The full text of Focus on Exceptional Children is also available in the electronic versions of the Education Index. It is also available in microfilm from Xerox University Microfilms, Ann Arbor, MI. Subscription rates: Individual, \$30 per year; institutions, \$40 per year. Copyright (C) 1996, Love Publishing Company. All rights reserved. Reproduction in whole or part without written permission is prohibited. Printed in the United States of America. Second class postage is paid at Denver, Colorado. POSTMASTER: Send address changes to:

$$
\begin{gathered}
\text { Love Publishing Company } \\
\text { Executive and Editorial Office } \\
\text { P.O. Box } 22353 \\
\text { Denver, Colorado } 80222 \\
\text { Telephone (303) } 757-2579
\end{gathered}
$$

Edward L. Meyen

University of Kansas

Richard J. Whelan

University of Kansas Medical Center
Stanley F. Love

Publisher
Glenn A. Vergason Georgia State University they are effective in teaching most students. Another negative consequence is the abandonment of effective methods because some students do not learn as expected. The myth contributes to fads in education, a search for magic rather than best practices grounded in scientific evidence (cf. Carnine, 1993). It supports hucksterism in education and creates suspicion of the claims of even the most careful educational researchers.

The whole truth, however, is that although some methods are much more effective than others, no instructional method we know of - not even the best method implemented flawlessly - actually produces success for all. This likely will always be the case, given the variety and complexity of human beings. Today's educational reformers are infatuated with the idea that if various aspects of schooling are restructured correctly, a single type of class, school, curriculum, track (or nontrack), or instructional approach will produce success for all. If "all students" is taken literally, all such claims literally are false; if "all students" is not taken literally, those who claim success for all must say who is not included (Kauffman \& Hallahan, 1993).

Direct instruction is an approach to teaching that grew out of careful logical analysis of the tasks of teaching and extensive field testing of teaching procedures (e.g., Carnine, Silbert, \& Kameenui, 1990; Engelmann \& Carnine, 1982; Silbert, Carnine, \& Stein, 1981). It clearly has been shown to be effective for teaching the vast majority but not quite all students (cf. Carnine et al., 1990). The following demonstrates one teacher's experience with direct instruction.

For years, I have used direct instruction for teaching children with mild mental retardation. My preference for direct instruction began during the second year I taught these kids. Twin girls with much lower IQs and a more dysfunctional family than any of my other students were placed in my selfcontained class. Much to my amazement, these girls read circles around the rest of my kids. For a while, I feared for these little girls' lives! They were the youngest, smallest, and least tactful students in my class. They thought nothing of saying to my other students, "Golly! You can't read that? Are you retarded or something?!"

The twins were age-appropriate fifth graders. The rest of the kids in my class were sixth and seventh graders who had been retained at least once- - big kids who didn't like insinuations that they were less talented than these tiny, tactless little girls. In the interest of preserving life (of the twins), I scurried around and found out what and how their teacher had taught them previously. She had used direct instruction. So I read everything I could find about direct instruction and learned that the research was overwhelmingly supportive of using it with at-risk students. I figured that students with mild mental retardation were definitely at risk. So I soon became proficient in direct instruction and used it very, very successfully for years with many different kids. Until I met Benjamin.

Benjamin was autistic, and he decided he wasn't about to let me have the control over him that I had to have with direct 
instruction. No amount or kind of reward I could find would induce him to participate in direct instruction lessons. "Give him more choices, lots of choices," the gurus of education said. I did. He wouldn't budge. In desperation one day, I approached him when he was looking at his favorite book. "Do you like that book?" I asked, like a ninny (it was obvious that he did). "Yep," he said.

"Would you tell me what you like about it, and I'll write it down?"

He rambled, made no sense, and wove his daily life into the story. I wrote it all down, asked him which words he wanted to learn, and he told me! I switched to the language experience approach (LEA) for Benjamin's reading instruction. I always had used this method as a supplement to direct instruction or as a reward for work completed correctly, but I had not used LEA as the primary approach with any of my students. In my 25 years of teaching, Benjamin is one of only three kids for whom direct instruction was not successful.

Sometimes, because of a new fad or a shift in someone's educational philosophy, administrators or supervisors tell general education teachers to use only one instructional method. And sometimes these teachers get stuck with methods that simply don't work for the kids they teach. Several years ago I taught a student with Down syndrome, who thrived on direct instruction in my special class. She learned to read in her first year, and at the end of that year, her mother asked that she be mainstreamed for reading with the first graders beginning in the fall.

Janice started the year with a group of students who had been retained in the first grade and who were being taught using a whole-language approach. The general education teacher had requested that she be allowed to use another reading method with these students, but the administration denied her request. Whole language was to be used with all kids.

Not long thereafter, Janice was the star of the group, and the other children wondered why she could read better than they could. They were the same age as Janice, and had the same amount of reading instruction, and she clearly had mental retardation. "Mrs. Batten," one boy in the group remarked, "Janice looks funny, but she sure can read!"' They couldn't understand. The only person more frustrated than the students was Mrs. Batten, the teacher!

Myth \#1 should remind us to strive to find and use the most effective instructional methods, to pursue the goal of helping all students learn as much as possible. The pursuit of that goal requires that we choose instructional approaches on the basis of reliable empirical evidence of their effectiveness but that we also be candid about cases in which any given approach fails and search for an alternative that does work with those individuals. The myth should prompt us to use first and with most students the approach that extensive field testing has shown produces the best results for the greatest percentage of students. The absence of careful, scientific field testing or a high rate of failure to learn should be a sufficient basis for avoiding an instructional method regardless of any philosophical bias we may have. Try the best method first; try alternatives when it fails.

\section{MYTH \# 2}

\section{Students receive intensive, individualized instruction if they are taught in a special class or resource room.}

We wish this were not a myth, as its untruth reveals one of special education's greatest failures. Placement in a special setting should mean that the student gets truly special education-something decidedly different from and superior to the instruction provided in the general education classroom, more intensive and more highly individualized. The myth is perpetuated by special education's historic intention to provide individualized, intensive instruction, by the law which says that such special education should occur, and by program personnel who would like to see their program praised for what it should be.

The myth has negative consequences, as it allows administrators who set up special classes to assume that the instruction students receive therein will be special. It also allows teachers to justify what they do in a special class under the guise of special education. And it allows parents to assume that their children are getting the instruction they need when they are placed outside the general education classroom.

The whole truth is that students can get excellent, individualized instruction in special classes and many of them do. Too many, however, receive only what they would get in a general education classroom or, in some cases, worse. Special classes and resource rooms provide opportunities to teach students in small groups, to offer more intensive, focused, and effective instruction. The shame of special education is not that these opportunities are provided in pull-out settings but that special educators too often are untrained or are unwilling to take these opportunities (Kauffman, 1994).

The intense small-group and individual instruction that should be a hallmark of special education classes is lost when classes are too large. Even the best of teachers can be swamped by excessive demands. Also, however, some teachers make bad choices of what and how to teach students with special needs. Students may not receive the special instruction they should in a special class or resource room for a variety of reasons, as the following account illustrates.

I haven't always enjoyed teaching children with special needs. There have been some years when my aide and I closely perused the "help wanted" section of the newspaper every afternoon after the kids left. We decided that cleaning houses, digging ditches, or washing windows from a scaffold would be less tiring and more lucrative than teaching.

We were never as stressed as we were the year Jeremy came. In the spring, all of the special classes for children with mild mental retardation were full (at or over the state limit). Some of us pleaded with administrators to open a new class for the fall. If preceding years were any indication, the system would declare a number of children in the system eligible for 
services after the year started. And there were always eligible students who moved into our area. But less money was available than in previous years, so salary for a new special education teacher was not in the budget.

Predictably, a new student, Jeremy, moved to our system from another state. Our supervisor asked the superintendent to sign another waiver for him to be placed in my class. He did, and Jeremy came. My class limit was 12 . Jeremy was number 17.

Jeremy's educational plan was troubling. Even though he was a third grader, with an IQ score well above some of my other students, all the academic areas were categorized as "pre-readiness." Even my kindergarten students were ahead of Jeremy academically! It was clear from the information in the psychological folder that Jeremy would probably be lost in even my most delayed academic group and would require individual attention for academics.

I was fortunate to have a talented and skillful student teacher that year, who took over some of my other groups so I could devote several blocks of time to Jeremy. He soon let me know that he did not appreciate the effort! Even though I had tried to be very reinforcing of any effort on his part, he clearly was not going to go quietly to the academic trough. He whined, cried, screamed, and usually refused to participate in any instruction. I allowed him to make as many choices as possible during every lesson, reduced the length of the lessons, and increased the reinforcement. But his resistance increased. He also added verbal aggression toward me. When his mother came to observe a lesson (at my insistence), she said, "Well, of course he's unhappy. You're making him do things!"

The things I insisted he do were to trace his first name, to match four letters of the alphabet, to count objects (no more than 10). I had determined from the IEP what skills he had, planned highly structured lessons with lots of built-in choices for him, and rewarded him with objects he had requested (stickers, free time, stars on his papers). And he got meaner every day!

I asked his mother for a description of Jeremy's day at his previous school. There had been no small group or individual instruction, only whole-class instruction. His day started by finding the day on the calendar, determining the day's weather, and stating what was appropriate to wear. "They sang a lot of songs that were academically reinforcing, such as the alphabet song. Jeremy knows a lot of songs." Jeremy's mother had volunteered regularly in this class and was impressed with the amount of artwork the children did. Every day they spent an hour or more (never less) on art, a half-hour exercising (even though they also had a regular gym class), and had a safety lesson.

"Mrs. Wheatley, Jeremy's teacher, also showed a lot of wonderful films and slides," she said. She went on to tell me all about the films and the picture books the children could look at afterward.

When I asked if Jeremy was writing on lined paper in his former school, she said, "They weren't ready to write yet."

I was angry. Here was a third-grade child with an IQ of 65 who had not participated in any mainstreaming program (his class went everywhere en masse and separately) and had had little or no academic instruction. It wasn't that I disapproved of Mrs. Wheatley's projects. I, too, taught the calendar, sang songs, did art, and discussed safety. I also thought it important that the children learn to write their names!
Usually, my aide, student teacher, and I switched groups often so I could keep an eye on all my students. When Jeremy came, I wasn't as flexible. I didn't want to ask those with less training to handle a very difficult child. But soon the behavior problems in the other groups made themselves known. I had 17 children and five reading groups, and it soon became apparent that I needed a half-hour somewhere for another reading group. My aide voiced my opinion: "Pat, we've got too many individuals to individualize." Indeed!

Myth \# 2 should remind us of at least three realities about special education service delivery.

1. There is no magic in placement; a place is only as good for students as the instruction they receive there.

2. Teaching can be effective occur only if the numbers and level of support are manageable for the teacher.

3. Without appropriate training, monitoring, and support of teachers, special education services will deteriorate, regardless of their physical location.

If we want special education to be successful, it must have the necessary support of an infrastructure, including rigorously tested curriculum materials and instructional methods and support services from administrators, consultants, and paraprofessionals (Worrall \& Carnine, 1994).

\section{MYTH \# 3}

\section{Rewarding students' desirable behavior or academic performance inevitably undermines their self-control and intrinsic motivation.}

Behavioral methods always have had detractors. One of the myths perpetuated most fiercely is that rewards undercut the development of moral, self-directed persons. The myth is maintained in part by critics who have found evidence that, under certain conditions, rewards can undermine motivation. Furthermore, a widely accepted social ethic suggests that desirable behavior should be its own reward. The notion that children should learn to behave out of a perception of right and a desire to be good is appealing but it has been popularized by individuals who are not teachers and who have had little or no experience working with children who have serious behavior problems (e.g., Kohn, 1993). The myth appeals to those who out of philosophical bias or lack of energy would like justification for failing to provide rewarding consequences.

The negative consequences of this myth include the refusal or abandonment of positive behavior management strategies. This is especially unfortunate because students with emotional or behavioral disorders, like their general classroom peers, are likely to receive little positive attention from their teachers (Shores et al., 1993; Strain, Lambert, Kerr, Stagg, \& Lenkner, 1983).

The whole truth is that structuring rewarding consequences 
is an indispensable part of rearing and teaching prosocial children. Rewards can be used skillfully or clumsily, and research shows that skillfully used rewards seldom, if ever, undermine self-control and intrinsic motivation (Cameron \& Pierce, 1994). True, what is rewarding for one student may not be for another and offering rewards that are not meaningful is useless. True also is that rewards for tasks that the student sees as trivial are likely to be ineffective and undermine motivation, but rewards for accomplishments that the student sees as difficult are gratifying and motivating. According to teachers' personal experiences as well as extensive field research, rewards for appropriate behavior are necessary and effective in managing and teaching difficult students. The skillful use of rewarding consequences can help "tough kids" and antisocial students learn academic and social skills and become more self-directed and internally motivated (see Rhode, Jenson, \& Reavis, 1993; Walker, Colvin, \& Ramsey, 1995). Of course, we want students to respond ultimately to "natural" social rewards. The following illustrates the kinds of effects researchers have documented repeatedly.

In my wanderings around the school, observing my students in the general education classrooms, I was aware that many of the children in the general education classrooms were intrinsically motivated. Or so it seemed. I also saw many of the same motivated students in the afternoon, when their moms or dads picked them up. These parents praised the work handed them, patted a head or two, and even gave hugs for good work. Most of the motivated students, including the rare motivated soul in my room, had parents who were very much involved with their children's educational progress. These parents came to school, praised the teachers and the students, and responded to notes and phone calls from the school.

At times I have stooped to using the power gained from having involved parents as a weapon of guilt. "What would your mother say if she saw this paper? Do you think she would be happy to see this messy paper?" Almost always the recipient of this guilt quietly removed the paper from my hands and did it over. These students cared what their mothers thought because they knew their mothers cared about them. That's a powerful motivator.

But what about the student who has failed time and again with academic lessons? Or has a stressful home that could be used as a case study for a dysfunctional family? What about the one whose life seems to be an intrinsic hell?

Andy started in my class on Valentine's day. He was no Valentine. He didn't think teacher directions ("It's time to line up for lunch") were important. When Andy wanted to play in the free-time area, he expected to be allowed to do so, and he protested loudly when he wasn't. In short, Andy wanted to do what he wanted to do when he wanted to do it without any interference from anyone, including teachers. He reminded me of a line from a Bogart movie: "I want what I want when I want it." Andy soon found out that I was not Lauren Bacall.

After Andy had been at school for 2 days, his teacher from the previous school in another system called me. She was loaded with information about his family and academic infor- mation not included in the psychological folder, such as cues to give him to stop some of his undesirable behavior.

I also made a home visit. Andy's mother, Mrs. Johnson, received me in her immaculately clean dining area. She never looked at the IEP changes I wished to make in Andy's educational plan. She never looked at me. She looked at the razor strap on the table. The strap had a leather thong in the top, which she pulled onto her wrist. Twice while I was there, she banged the strap on the table when one of the children was too loud or too close for her comfort. Mrs. Johnson signed the addendum to the IEP, and I left. I also vowed that Andy would get lots more attention from me, my aide, the principal, the speech pathologist, and anybody else I could strong-arm into doing a favor for me.

It was imperative that we get Andy in his seat and get him to stay in his seat and complete work that his previous teacher assured me he could do. He was fascinated with the box of shells I had collected at the beach the previous summer. I sorted them into sizes and promised him one of the tiny shells for every problem he worked correctly. I had bags and bags of shells at home that had cost me nothing, and he loved them. Soon he asked, "Instead of all those little shells, how about if I get a bigger one for a whole sheet?" We discussed that the papers had to be neat, mostly correct, as well as completed. He thought that was fair. My aide found an old pencil box, covered it, and helped him glue his shells onto the box-a treasure chest. In the meantime, I sent him with good notes all over the school-to the principal, the guidance counselor, the secretary, and anybody else who expressed an interest in Andy.

Andy's work habits improved. His behavior improved. After a while he began to give his shells to the younger children in the class or back to me at the end of the day. Before long a sticker on his paper displayed on the bulletin board was enough for him.

Instead of going to the guidance counselor, principal, or secretary for stickers for his papers, he began to give his good papers to them, happy for their praise and their thanks.

The following year, Andy needed much less reinforcement. He seemed proud just to finish a paper ("I do good work, don't I?").

I wonder what would have happened if I had continued to expect him to complete seatwork without any reinforcement for his efforts. How can you undermine self-control and motivation that don't exist?

Myth \# 3 should remind us that our ultimate goal is students who are internally motivated, self-controlled, and self-actualized. We should be cautious in choosing and offering rewards so they do foster moral, self-directed behavior and produce students who want to do what is right. It should remind us that rewards without an effective instructional program are in vain (Kauffman, Mostert, Nuttycombe, Trent, \& Hallahan, 1993).

\section{MYTH \# 4}

\section{The general education classroom in the neighborhood school is the least restrictive environment (LRE) for all students.}

This myth is based on a misunderstanding of environments and their restrictiveness. The notion of normalization-making 
the environment as "natural" or as close as possible to what is considered normal - seems to suggest that the school and class a student would attend if he or she had no disability is necessarily the environment that is least restrictive. This myth is sustained by a misunderstanding of issues involved in segregation, a devotion to the ideology of inclusion, ignorance or rejection of research on placement, and denial of ecological principles pointing to the need for specialized social environments for some students (Kauffman \& Hallahan, in press). The myth is appealing because of its simplicity (one placement for all students) and egalitarianism (students are not physically separated from the mainstream, so they are assumed to be integrated and treated equitably).

The negative consequences of this myth include the placement of some students in general education classrooms in which neither they nor their classmates can be well served and the abandonment of pull-out programs and special classes and schools that are the LRE for some students. It contributes to conflict and anxiety, as some professionals and parents believe optional placements will be withdrawn for students who need them. And it is a misinterpretation of the law (Individuals with Disabilities Education Act, IDEA) that may lead to legal violations.

The whole truth is that, although the general education classroom is the LRE for many students, some need the special restrictions offered in alternative settings. The LRE must be an environment in which a student can meet the objectives of his or her IEP without endangering self or others, and this environment almost certainly will not be the general education classroom for all students (cf. Bateman \& Chard, 1995; Kauffman \& Hallahan, in press).

Deciding what is the LRE for an individual student is no small task. It requires careful judgment of the student's characteristics and needs and what can be offered in different environments. By law, the decision about LRE must be made on an individual basis and by educators in collaboration with the student's parents. The law does not require that a student first fail or endanger someone before an environment other than the general education classroom can be considered (cf. Bateman \& Chard, 1995). Contemplate the following teacher's experience.

Mrs. Anderson, a first-grade teacher, came to the first child study meeting of the year. She described George's behavior, which frightened her and the other children. Besides being nearly totally noncompliant (he followed about 3 percent of instructions, she said), he was violent, aggressive, and abusive to himself and to others. Some of us thought we should refer him immediately for a full evaluation, but one of the administrators demanded that we first try strategies in Mrs. Anderson's class before referring George. Mrs. Anderson was visibly upset when she left the meeting, armed with a list of strategies we "experts" had given for a child we had not yet observed.
Mrs. Anderson faithfully followed the strategies, documented the results, and came back 2 weeks later. George was not any better. She described George's daily fights with his classmates. She also related how he had stolen a tooth from a child's backpack. Mrs. Anderson's student teacher had made a "tooth fairy" booth for students who lost their baby teeth at school. When someone lost a tooth, they got a fancy envelope with an equally fancy card informing the child's parents that he had lost a tooth at school. The envelope also contained a large sticker of a fairy with iridescent wings. George stole the envelope from the student's backpack and put it in his backpack. The student teacher gently but firmly explained to him that when he lost a tooth, she would fix him a fancy packet to take home. But until then, the envelope was not his, and it was wrong for him to take it. George was playing with some small plastic blocks. He put one in his mouth, chomped hard on it, broke his tooth, and handed it to the student teacher. "Now, give me a packet," he demanded through bloody lips. The school nurse corroborated the story.

This was enough for me. We needed to refer this student for full evaluation, and quickly. But the acting principal didn't agree. When I went to him privately to plead the case for George to be evaluated for possible special education services, he said, "You women will just have to get used to active little boys. I've observed George. He's just active."

George's fighting, cursing, and stealing increased in spite of our best efforts. The resource teacher provided relief for the first-grade class by picking him up as much as allowed. But George's behavior worsened. Mrs. Anderson refused to plead his case before the child study committee any more. "What does it take to get you people to refer a student? Murder? Suicide?"

On the playground one day, we watched George stomp a dead bird until all the innards were oozing onto the grass. He cackled and laughed all the while. He struck me when I tried to get him to stop throwing rocks with deadly aim at my students on the playground. And Mrs. Anderson told me about a chilling moment when he stroked one of her breasts and said, "This'll be our secret. Don't tell anyone, and we can do it again."

Anyone can refer a student to the child study committee, so even though George was not one of my students, I made a referral to the committee, hoping that Mrs. Anderson would come to the meeting. It was now December, almost time for Christmas break.

George made sure I didn't have to bother presenting the data to the child study committee. At the end of our library is a stairwell that is the focus of our open school. The stairs are perfectly safe, surrounded by chest-high (my chest, at least) railings of vertical iron bars with a cap and are monitored closely by teachers to prevent their classes from running on them. Physical education and music classes are on the basement floor, so students march up and down these stairs all day. Sometimes I got to chat with teachers waiting at the top of the stairs for their aides to bring students from gym or music.

Mrs. Anderson was standing by the railing when I was on my way to pick up some of my students from art. I spoke to her. She didn't respond. I stopped but she didn't acknowledge me. "What's the matter?" I asked. "Don't say anything," she breathed. "Look." George was on the inside of the stairwell, swinging by his hands from bar to bar. He had moved over the highest part of the well, the longest drop. It was only a one- 
story drop, but that was far enough for a six-year-old boy to hurt himself seriously. Mrs. Anderson told me later that every time she had reached for George, he swung away, "And he wasn't very careful about how he did it." Neither of us was tall enough to grab him from the bottom, either. When he was concentrating on which bar to grab next, I ran for the acting principal. "Your active little boy is about to commit hari-kari in the first grade stairwell," I panted.

George was retrieved safely. I have to admit to a bad case of nerves. I didn't watch. But George was referred for a full evaluation (that very day, as I recall). He was evaluated and the data were discussed at an eligibility meeting. George was declared eligible for services as a special education student. When the IEP was written, it was decided that he should be served in a class for students with serious emotional disturbances, but he had to be moved from his first class. The class was on the second floor of an old building with big windows, and George kept trying to jump out of the window. After he was moved to another school (with only one floor), he tried repeatedly to run away, and his violence escalated. When I last heard of him, he was at the last step before hospitalization. I never heard whether that highly structured, special public school was successful, but I do know that his emotional disabilities were so severe that he could easily have killed himself in his neighborhood school. Being dead is more restrictive that being in a special school or even a hospital.

Myth \# 4 should remind us to make decisions about students' placement with utmost care. Some students are placed in needlessly restrictive environments, and we should be constantly seeking ways to make more ordinary, everyday environments such as general education classrooms adequately supportive of students with disabilities. It also should remind us that we can ignore the need for an alternative placement for too long.

\section{MYTH \# 5}

\section{Attending a special class or school always harms a student's self-concept.}

The observation that there is often pain in being different, from being excluded from an in-group, or being included in a group of outsiders, makes this myth seem like common sense to many. We all can tell stories of lowered self-appraisal associated with feeling set apart or left out, and in truth we know that some students feel this kind of hurt when they attend a special class. The myth is perpetuated by stories of spoiled identity and by the overgeneralization from these reports to include all students. It is fostered by those who believe that all special classes and schools represent unethical segregation. It is an appealing fantasy to believe that being separated from the mainstream always demeans, whereas being with the majority is always self-enhancing.

The negative consequences of this myth include not only the denial of appropriate placement to some students but also the exacerbation of stigma for those who are placed outside the general education classroom. In a sense, this myth may contribute to a self-fulfilling prophecy, in which students begin to feel stigmatized because we describe special classes as undesirable and general education classes as better or preferable for everyone. More important, it denies the possibility that a positive self-identity can be fostered by associating with others who share one's exceptionality (see Hallahan \& Kauffman, 1994).

The whole truth is that the feeling of spoiled identity is not universal among students who attend special classes or schools. The taint of being special and going to a special class or school is for some students less stigmatizing and destructive of self-concept than struggling in a general education classroom where they constantly are comparing themselves and being compared invidiously to students who do not share their disabilities (cf. Coleman \& Minnett, 1993). For some students, being separated from the mainstream and becoming part of a special class in which their instructional needs are addressed effectively can be self-enhancing, as illustrated by the following.

Alice's first-grade teacher called about 5 minutes after the educational planner left my room. Both the first-grade teacher and the educational planner informed me that at the eligibility meeting the day before, Alice qualified for services in my class for children with mild mental retardation.

"It would be great if you could write the IEP for Alice soon so we could have her start right after Christmas," her teacher suggested. "She cries so much. I feel so bad for her. She's no problem, but she just can't do the work."

Legally I had 30 days before an educational plan had to be approved by the parents. It was just a few days before Christmas break, all the kids in the school had decided to have a nervous breakdown, and all the teachers were tired and crankyespecially me. My aide and I had the added fatigue of trying to ensure that all the students in my class received some presents for Christmas. I wasn't keen to add to my stress or my responsibilities, but both the supervisor and the first-grade teacher had pleaded with me to arrange a meeting with the parents as quickly as I could.

I spent the evening reading Alice's psychological folder. She had been in the preschool program for 3 years. The preceding spring, in an eligibility meeting, the school staff thought Alice qualified for services in my class beginning in September, but the parents felt otherwise. "Retardation" is such a dirty word. The present euphemism "class for children with mild mental disabilities," didn't disguise the fact for the parents that this was what some would call the "dummy class."

The father flatly refused to have Alice placed in my class. "Alice can do the work. I know she can," he said.

So Alice started out the year with new clothes, a smile, and the fine-motor skills of a 2-year-old. Although she was from a loving, attentive family that read to her and paid her a lot of attention, her skills were seriously delayed compared to the other students in the first grade. It wasn't that she didn't learn. She just took so much longer than the other children in her 
class. Even though Alice participated in the resource program, the speech program, the occupational therapy program (all done in the general education classroom and including other classmates in her lessons), she could not keep up with even the slowest group in her class.

Soon Alice was asking her mother, "Why can't I do what the other kids do? I want to do it." Motivation didn't seem to be a problem at first, but after a few months Alice decided not to try to try. I can't say that I blame her. After a while she made her misery known to all, both at home and at school. She became a helpless blob crying most of the time. Her teacher said, "As far as I know, no one in my class has ever been mean to Alice. She just purely hates school now." Alice's mother agreed with the teacher. "I've asked her over and over again if anyone has been mean to her. She says no, and I believe her."

After reading her folder and talking with teachers who worked with Alice, I felt badly for her, too. The parents and I wrote an educational plan for Alice, stating that she would begin attending my class after Christmas. The dad still wasn't so sure he approved, but he knew something had to be done. "But you have to promise to push her. She can be really manipulative," he warned.

After a few weeks of Alice's placement in my room, the parents and I met again. They seemed much happier. "Alice enjoys coming to school now," they let me know. The dad, much to his credit, wished he had not denied her services in the fall. "She feels so much better about herself now," he said.

Two years later, Alice's father and I talked about his reaction to the eligibility meeting (the one deciding that Alice qualified for my services). "There were so many people," he said, "and they were all saying that there was something terribly wrong with my daughter. I wondered who in the hell they were talking about! My pretty little girl is so loving and funny. How could they say she was retarded?'

"Does it matter what label they put on her? Isn't she still a pretty, funny, loving little girl?"

"Yeah," he laughed, "except now she can read!"

Myth \# 5 should remind us of the anxiety and fear of spoiled identity that students and parents may feel when the student's disability is identified and labeled and the student is placed in a special program, class, or school. It should sensitize us to the reality that special placements can undermine students' self-concept and alert us to ways to ameliorate those effects. Special placement demands special education that is self-enhancing.

\section{MYTH \# 6}

\section{All students benefit by having appropriate peer models in general education classrooms.}

A common argument in favor of mainstreaming or inclusion and against teaching students in special classes or schools is that in special settings students have no appropriate role models, whereas in general education they will have appropriate models to imitate (e.g., Rogers, 1993). This myth has great appeal in its "common sense" simplicity, for nearly everyone recognizes the potential power of observational learning.
Furthermore, the popular image of special classes includes negative stereotypes, whereas the general education classroom is stereotyped as one in which students are well behaved and learning. "How will children learn to behave if they have only the horrid examples provided by others with disabilities?" "Students with disabilities need to be alongside those who don't have disabilities, because the normal ones know how to behave and will be good examples." These are comments typically used to further the myth, although we note on second thought that they also cement the negative stereotype of students with disabilities, who are assumed to have primarily negative influences on one another.

The negative consequences of this myth include not only the inappropriate placement of some students in general education but also failure to note that if these students are to learn to imitate desirable models, they must receive explicit instruction. Another negative consequence is that teachers miss opportunities to use students with disabilities as appropriate models for one another in special classes and schools.

The whole truth is that most students with disabilities, like most other students, seem to learn unpredictably from appropriate peer models in the absence of an explicit imitation-training program. Moreover, for models to be effective, the observers must see themselves as being somewhat like the models - to identify with them. Finally, students may learn from inappropriate as well as appropriate models, and both desirable and undesirable models are found in nearly every classroom, both general and special education(see Hallenbeck \& Kauffman, 1995). Proponents of including all students in general education classrooms seem to assume not only that incidental observational learning will take place but also that what is learned will be positive. The following shows this is not always the case.

When I observed Albert just before Christmas in the resource room where he was taught one-on-one, he was noncompliant with reasonable requests ("Sit in your chair") and verbally and physically aggressive toward his full-time aide, his teacher, and his classmates on the playground. He had frequent tantrums, vomited and ate his vomitus, blew his nose and wiped the mucus on others.

Albert had not started his academic life isolated in the resource room. When his parents registered him at school, they requested that Albert be fully included in the general education classroom. Even though the psychological folder from a school in another state delineated Albert's difficult behaviors, the strong medications he took every day, and his institutionalization for 3 months the previous year, the school agreed to the parents' request. They placed him in a second-grade class. Albert was a rising third grader but was so small that parents and school administrators decided he would do better in the second grade.

I was consulting in this school. As part of this process, I interviewed the teachers responsible for Albert's education. 
Mrs. Tinsley, the regular second-grade teacher, had volunteered to have Albert as part of her class. She had special education training, had fully included other children with disabilities successfully in her class, and was looking forward to Albert's coming. Her second-grade class consisted of "mostly well-behaved, achieving students." Albert was coming to the Dream Team-to experienced teachers who wanted him and to classmates who would be good role models for him.

But Albert had not read the textbooks. He continued the unpleasant behaviors mentioned in the psychological folderwiping mucus on others when his will was thwarted, screaming constantly, vomiting (once into the printer because he didn't wish to stop using the computer), pulling and grabbing the other children's clothes, biting adults for no apparent reason other than that they were there. At first, according to Mrs. Tinsley, the other students wanted to help him. They became "big brother" or "big sister" to him. Most of the interactions his classmates initiated with Albert consisted of trying to cue him to comply with teacher requests and praising him on the rare occasions when he did-just what we would have taught them to do as peer confederates. Although a few students encouraged him to misbehave, most wanted to help him.

After a while, though, according to Mrs. Tinsley, the students were afraid and confused by Albert's behavior. School personnel could not find strong enough rewards (or effective response-cost procedures) to moderate Albert's behavior. He continued to vomit and eat it, to yell and scream. Even though all the teachers involved with Albert tried to cue him about appropriate and inappropriate comments, he still initiated conversations with classmates by asking them if they loved him or if they would marry him. He continued to pull and to grab the other children's clothing and tried to urinate on the boys when he went to the bathroom.

Albert gradually was isolated more and more in the resource room with his full-time aide. Because most of the resource students were taught in the general education classroom, Albert and his aide had the room to themselves much of the day. Even then, life was difficult, and many of the aberrant behaviors remained: the tantrums, the biting, the vomiting, and wiping his mucus on others. He added pinching to his repertoire. Albert became a despotic dictator who engaged in any and all of the aggressive behaviors mentioned if he did not get his way.

The aide and the teacher maintained a program of strict rules with sanctions for not complying and rewards for obeying. Gradually the aide and the teacher began to see moderate improvements in Albert's behavior. Although most of his problem behaviors did not disappear totally, Albert did establish a relationship with both the aide and the resource teacher and began to improve academically and behaviorally. Even then, he tested them periodically. The resource teacher remarked, "Just when I feel like I have a handle on this little boy, he proves me wrong."

Albert had what would seem to be the ideal situation for a student with disabilities-caring and competent teachers and general education peers who wanted to include him. Everyone (including the students in the second-grade class) wanted $\mathrm{Al}$ bert to succeed in the general education classroom. In spite of this ideal situation, Albert's behavior worsened in the general education classroom. He did not imitate the exemplary behavior of his peers in Mrs. Tinsley's class. He seemed incapable of forming any relationship with them, other than that of bully.
The resource room that became, in effect, a large isolation booth for Albert and his full-time aide was not a solution either.

The environment we believe would have been most helpful might be a small class of children with learning problems somewhat like his, including some who weren't as seriously disabled. This would have provided an opportunity for smallgroup instruction focused on Albert's specific academic and behavioral needs, including appropriate peer models with whom he could identify. He needed a group of peers with which to interact, but the gulf between himself and the general education classroom peers was too great for him to learn effectively by being expected to imitate them.

Myth \# 6 should make us reconsider where and how we expect to see imitation of appropriate behavior. It should remind us that the probability that students will learn automatically is low, that we typically must teach directly what we want them to learn, even if it is something as seemingly mundane as what to pay attention to and whom to imitate. It should make us more aware, too, of the kinds of models we find most helpful and the kinds of models our students are most likely to imitate.

\section{MYTH \# 7}

The landmark 1954 school desegregation decision of U.S. Supreme Court, Brown v. Board of Education of Topeka outlawed separate education for students with disabilities.

This is a popular myth sparked primarily by proponents of including all students in general education classrooms in their neighborhood schools - those furthering the full inclusion movement. Some have used Chief Justice Earl Warren's statement in the Court's ruling that "separate educational facilities are inherently unequal" (cf. Bartholomew, 1974, p. 47) with reference to separate schools for Black and White children to support the contention that any separation of students based on ability or disability is unlawful or unethical (e.g., Stainback \& Stainback, 1991). The myth is perpetuated by the assumption or explicit argument that skin color and disability are equal constructs before the law and that disability should have no place in determining the school or class a student attends.

More specifically, the core of the myth is the false assumption that the concept "separate is inherently unequal" applies legally, and equally to all manner of difference. The myth is maintained also by the assumption that the civil rights movements of racial minorities and of people with disabilities are based on the same arguments, particularly with reference to educational placement.

A negative consequence of this myth is that both racial discrimination and discrimination against students with disabilities are misunderstood. Special education placement decisions then are based on erroneous assumptions. The consequences of this myth are particularly severe when it is 
used to argue for policy changes that would involve all students with disabilities.

The whole truth is that although both racial minorities and people with disabilities have suffered discrimination and are supported by powerful social movements to guarantee their civil rights, race and disability are not equal constructs before the law; the civil rights involved are substantially different (for discussion of these differences, see Kauffman \& Lloyd, 1995; Semmel, Gerber, \& MacMillan, 1994).

Furthermore, under IDEA, the basic provisions of which date from 1975, it is illegal not to make separate educational placements available for students with disabilities who are determined to need them based on their IEPs. The law, however, does require that students with disabilities be placed in the LRE in which they can be provided an appropriate education, and this provision of the law must be taken seriously. While holding schools responsible for using alternative placements when appropriate, the courts also demand that schools make serious efforts to determine what is the LRE for individual students and to provide appropriate education in that environment (Huefner, 1994).

Three provisions of IDEA are particularly pertinent:

1. A continuum of alternative placements (CAP) must be available

2. The student must be placed in the LRE that is consistent with appropriate education

3. Appropriate education and placement must be determined on an individual basis.

Thus, automatically placing a student in a general education classroom, neighborhood school, or elsewhere violates procedural rights protected by IDEA (Bateman, 1994). In fact, the courts have upheld all three of these provisions regarding the placement of students with disabilities (Bateman, 1994; Huefner, 1994). The right to individual determination of placement options for the education of students with disabilities was not outlawed by Brown v. Board of Education. IDEA guarantees these options; the courts have upheld the legality of these options; and many parent and advocacy groups support continued availability of the continuum of placement options (see Kauffman \& Hallahan, 1995, Appendix, for examples).

Parents and educators have a right and a duty under the law to consider first the student's educational needs - to describe an appropriate education. Then they have a right and a duty to place the student in the LRE consistent with the student's educational goals. As Bateman (1994) points out in the next example, the LRE for some students may not be the neighborhood school or classes with peers who do not have disabilities.

In a fairly typical case, the U. S. Fourth Court of Appeals dealt with placement of 16-year-old Michael. His IQ was 72, his academic level was about fourth grade, he worked successfully at a fast-food restaurant, and he related well to other teenagers in several small continuing groups, although he did have some difficulties with communication and social skills. The court approvingly noted the lower court's conclusion that at Annandale High School, which served 2,300 students, few of whom were disabled, Michael had "no appropriate peer group academically, socially, or vocationally."

The court therefore upheld his placement at a vocational center 13 miles from his home, rather than at the public high school. The court also spoke to the fact that Michael would have been simply monitoring classes at the high school and said the disparity between his cognitive level and that of the other students would mean he would glean little from the classes and his work would be at a much lower level than his classmates (DeVries v. Fairfax County School Board, 1989).

Myth \# 7 reminds us that we need to pay more than lip service to the concepts of CAP and LRE (Huefner, 1994). While exploding the myth, we should give more attention to making certain that the environments in which we place students not only are truly habilitative but also the least restrictive ones in which our goals for students can be reached. Too often, either the spirit or the letter of the mandates of IDEA is mocked by our practices. Myth \# 7 draws our attention primarily to the LRE, which may be made a mockery in either of two ways:

1. By reducing LRE to a single placement (general education classroom alongside nondisabled peers).

2. By failing to consider placement in a more normalized setting out of ignorance, prejudice, fear, or torpor.

\section{MYTH \# 8}

\section{We would, if we could, eliminate labels and simply provide all students the services they need without categories or labels.}

This is one of the most persistent, "hard-core" myths of all social services, including special education. Its appeal is heightened by the observation that most categories and labels associated with special education (a) often carry stigma and can be used in demeaning ways, (b) are imprecise descriptions of need, (c) sometimes are assigned wrongly, (d) may not result in the student's getting appropriate services, and (e) are difficult to remove or forget. Understandably, people may be disgusted at what they come to see as a useless and damaging process and argue for abandoning labels. They say, in effect, "Let's give kids what we know they need without labeling them; let's label the services, if we must, but not the kids" (cf. Lipsky \& Gartner, 1991; Reynolds, 1991). The myth has great appeal because we want to avoid "pigeon-holing" children, and we would like to see that students get what they need with a minimum of stigma attached. When we find that someone is stigmatized, labels seem the obvious culprit. 
The primary negative consequence of this myth is that energy is diverted from real problems to pseudo problems. The real issues are the meanings we attach to disabilities, not the fact that we label them. Moreover, if we lose labels for students' disabilities, we lose our ability to advocate effectively for them.

The whole truth is that, although labels may create problems, we cannot communicate without them; they are absolutely indispensable in discourse. Furthermore, labels, categories, and the things they denote and connote become attached to people who receive services whether we intend to label the people or not. If we label programs and not people's characteristics, we run the risk of inaccurate communication about people. The problems associated with labels are not so much a function of the labels themselves as what is communicated by them - the concepts, the connotations to which they refer. Moreover, some labels are applied formally and officially by a social agency; others are attached informally and unofficially by members of a social group.

For example, in The Bird Artist (Norman, 1994), the novel's central character is legally acquitted of murder, but he lied as a witness and the community attached its unofficial label to him. "If you lie, you become the lie. Everyone knows that, too. ... It was as though I had become two people: Fabian Vas, and Fabian Vas the murderer" (pp. 241-242).

Feniak (1988) reported a relevant attempt at reform of special education labeling in England and Wales. There, sentiment for integration and egalitarianism, in addition to concern over the stigma associated with labels, was high. This led to legislation abolishing traditional special education categories and labels and substituted labels for the curricula students received. The intention was to do what Reynolds (1991) and others have suggested: Label programs, not students.

The abolition of official categorical labels for students had precisely the opposite effect of that intended by advocates of reform. Students were still labeled, but only unofficially and covertly. More troubling, however, was that the absence of labels obscured the extent to which students' special needs were being met. Monitoring became substandard because insufficient records were kept about individuals (one cannot assess the appropriateness of services received when all that is known is that a student receives them). As Feniak wrote:

It is difficult to know how students are chosen to receive either a "developmental" curriculum, a "modified" curriculum, or a "mainstream plus support" curriculum since the new [reporting] format drastically reduces the amount of information which is supplied. . . . The net result is that the needs of these students are not being addressed. (p. 122)

In short, a logical or sociological analysis, in addition to actual experience in trying to avoid special education labels, in- dicates the utter futility of the effort. Furthermore, the focus on labels obscures the more important issue of the denotative (explicit or objective) and connotative (implied or subjective) meanings we attach to the concepts to which the labels refer. Burbach (1981) summarized his sociological analysis of the problem of labels as follows:

An examination of selected aspects of the symbolic process reveals that human beings name things and subsequently build upon composites of denotative and connotative meaning around each thing named. These meanings are categorized and assimilated as more or less discrete units and can be activated in the process of thinking and communicating by a smaller representation of words. The significant point is that the naming (labeling) and categorizing of things is an inherent function of human language acquisition and usage (pp. 363-364, emphasis in original).

This is an important point because there is a persistent tendency among officials to frame the labeling questions in terms of whether they should or shouldn't label anomalous individuals. At the very least, this is a superfluous question; at worst, a diversionary one. If, in the strictest linguistic propriety, we can recognize and accept the fact that we label and categorize all people in the normal process of apprehending and organizing our world, we can then proceed to a more accurate formulation of the problem. (p. 374)

Although Myth \# 8 is not likely to be abandoned by lay persons who are troubled by stigma, as professional educators we should come to grips with the fact that labels are an inevitable part of discourse. Nevertheless, the myth should remind us to be careful how we talk about each other, to neither be captured by the ceaseless search for euphemisms nor use language that is harsh, insulting, and demeaning. It should caution us to avoid the careless use of categories and to remember always that no category or label comes close to telling us everything we need to know about a person if we are to interact caringly with him or her. Most important, it should remind us to work more diligently on correcting and humanizing the meanings we attach to labels for disabilities, to strive for greater understanding of what it means and does not mean to be a person with the particular characteristics we label.

Replacing myth with fact is a worthwhile endeavor, but it has its hazards. While salvaging a fragment of truth, we must be careful not to create a new myth from the shard. Our hope is that we have not created any new myths from those we may have exploded.

\section{REFERENCES}

Bateman, B. D. (1994). Who, how, and where: Special education's issues in perpetuity. Journal of Special Education, 27, 509-520.

Bateman, B. D., \& Chard, D. J. (1995). Legal demands and con- 
straints on placement decisions. In J. M. Kauffman, J. W., Lloyd, D. P. Hallahan, \& T. A. Astuto (Eds.), Issues in educational placement: Students with emotional and behavioral disorders (pp. 285-316). Hillsdale, NJ: Erlbaum.

Burbach, H. J. (1981). The labeling process: A sociological analysis. In J. M. Kauffman \& D. P. Hallahan (Eds.), Handbook of Special Education (pp. 361-377). Englewood Cliffs, NJ: Prentice Hall.

Cameron, J., \& Pierce, W. D. (1994). Reinforcement, reward, and intrinsic motivation: A meta-analysis. Review of Educational Research, 64, 363-423.

Carnine, D. (1993, December 8). Facts, not fads. Education Week, 40.

Carnine, D., Silbert, J., \& Kameenui, E. J. (1990). Direct instruction reading ( 2 nd ed.). Columbus, $\mathrm{OH}$ : Merrill.

Coleman, J. M., \& Minnett, A. M. (1993). Learning disabilities and social competence: A social ecological perspective. Exceptional Children, 59, 234-246.

DeVries v. Fairfax County School Board, 882 F.2d 876, (4CA, 1989).

Engelmann, S., \& Carnine, D. (1982). Theory of instruction: Principles and applications. New York: Irvington.

Feniak, C. A. (1988). Labelling in special education: A problematic issue in England and Wales. International Journal of Special Education, 3, 117-124.

Hallahan, D. P., \& Kauffman, J. M. (1994). Exceptional children: Introduction to special education (6th ed.). Boston: Allyn \& Bacon.

Hallenbeck, B. A., \& Kauffman, J. M. (1995). How does observational learning affect the behavior of students with emotional or behavioral disorders? A review of research. Journal of Special Education, 29, 45-71.

Huefner, D. S. (1994). The mainstreaming cases: Tensions and trends for school administrators. Educational Administration Quarterly, 30, 27-55.

Kauffman, J. M. (1994). Places of change: Special education's power and identity in an era of educational reform. Journal of Learning Disabilities, 27, 610-618.

Kauffman, J. M., \& Hallahan, D. P. (1993). Toward a comprehensive delivery system for special education. In J. I. Goodlad \& T. C. Lovitt (Eds.), Integrating general and special education (pp. 73-102). Columbus, OH: Merrill/Macmillan.

Kauffman, J. M., \& Hallahan, D. P. (Eds.). (1995). The illusion of full inclusion: A comprehensive critique of a current special education bandwagon. Austin, TX: Pro-Ed.

Kauffman, J. M., \& Hallahan, D. P. (in press). A diversity of restrictive environments: Placement as a problem of social ecology. In J. W. Lloyd, E. J. Kameenui, \& D. Chard (Eds.), Issues in educating students with disabilities. Hillsdale, NJ: Lawrence Erlbaum Associates.

Kauffman, J. M., \& Lloyd, J. W. (1995). A sense of place: The importance of placement issues in contemporary special education.
In J. M. Kauffman, J. W., Lloyd, D. P. Hallahan, \& T. A. Astuto (Eds.), Issues in educational placement: Students with emotional and behavioral disorders (pp. 3-19). Hillsdale, NJ: Lawrence Erlbaum Associates.

Kauffman, J. M., Mostert, M. P., Nuttycombe, D. G., Trent, S. C., \& Hallahan, D. P. (1993). Managing classroom behavior: A reflective case-based approach. Boston: Allyn \& Bacon.

Kohn, A. (1993). Punished by rewards. New York: Houghton Mifflin. Lipsky, D. K., \& Gartner, A. (1991). Restructuring for quality. In J. W. Lloyd, N. N. Singh, \& A. C. Repp (Eds.), The regular education initiative: Alternative perspectives on concepts, issues, and models (pp. 43-56). Sycamore, IL: Sycamore.

Norman, H. (1994). The bird artist. New York: Picador USA.

Reynolds, M. C. (1991). Classification and labeling. In J. W. Lloyd, N. N. Singh, \& A. C. Repp (Eds.), The regular education initiative: Alternative perspectives on concepts, issues, and models (pp. 29-41). Sycamore, IL: Sycamore.

Rhode, G., Jenson, W., \& Reavis, H. K. (1993). The tough kid book: Practical classroom management strategies. Longmont, CO: Sopris West.

Rogers, J. (1993, May). The inclusion revolution. Phi Delta Kappa Research Bulletin No. 11.

Semmel, M. I., Gerber, M. M., \& MacMillan, D. L. (1994). Twentyfive years after Dunn's article: A legacy of policy analysis research in special education. Journal of Special Education, 27, $481-495$.

Shores, R. E., Jack, S. L., Gunter, P. L., Ellis, D. N., DeBriere, T. J., \& Wehby, J. H. (1993). Classroom interactions of children with behavior disorders. Journal of Emotional \& Behavioral Disorders, 1, 27-39.

Silbert, J., Carnine, D., \& Stein, M. (1981). Direct instruction mathematics. Columbus, $\mathrm{OH}$ : Merrill.

Stainback, W., \& Stainback, S. (1991). A rationale for integration and restructuring: A synopsis. In J. W. Lloyd, N. N. Singh, \& A. C. Repp (Eds.), The regular education initiative: Alternative perspectives on concepts, issues, and models (pp. 226-239). Sycamore, IL: Sycamore.

Strain, P. S., Lambert, D. L., Kerr, M. M., Stagg, V., \& Lenkner, D. A. (1983). Naturalistic assessment of children's compliance to teacher's requests and consequences for noncompliance. Journal of Applied Behavior Analysis, 16, 243-249.

Walker, H. M., Colvin, G., \& Ramsey, E. (1995). Antisocial behavior in school: Strategies and best practices. Pacific Grove, CA: Brooks/Cole.

Worrall, R. S., \& Carnine, D. (1994, March). Lack of professional support undermines teachers and reform-A contrasting perspective from health and engineering. Unpublished manuscript, National Center to Improve the Tools of Educators, College of Education, University of Oregon, Eugene. 